\title{
SPECT/CT quantification of lower limb perfusion: The next frontier in radionuclide perfusion imaging?
}

\author{
Yiu Ming Khor, MBBS, MMed, MRCP, ${ }^{\mathrm{a}}$ and Sharmila Dorbala, MD, MPH ${ }^{\mathrm{b}, \mathrm{c}}$ \\ a Department of Nuclear Medicine and Molecular Imaging, Singapore General Hospital, \\ Singapore, Singapore \\ b Division of Nuclear Medicine, Department of Radiology, Brigham and Women's Hospital, \\ Boston, MA \\ c Cardiac Amyloidosis Program, Division of Cardiology, Department of Medicine, Brigham and \\ Women's Hospital, Boston, MA
}

Received Nov 27, 2019; accepted Nov 27, 2019

doi: $10.1007 / \mathrm{s} 12350-019-02020-3$

\section{See related article, pp. 1923-1933}

In this issue of Journal of Nuclear Cardiology, Chou et al reported the findings from their prospective, singlecenter study that evaluated the utility of SPECT/CT imaging of the lower extremities as an imaging biomarker for exercise tolerance and cardiovascular fitness ${ }^{1} .31$ patients scheduled for clinically indicated exercise stress and rest Tc-99m tetrofosmin myocardial perfusion imaging were recruited and underwent post stress and rest SPECT/CT imaging of the lower extremities. The investigators manually segmented individual calf muscle of interest (tibialis anterior, soleus and gastrocnemius) of each leg on low-dose CT attenuation images and quantified the perfusion reserve of each muscle, defined as the relative percentage change in Tc-99m tetrofosmin uptake from rest to stress condition. The results showed that perfusion reserve of the muscle groups was significantly associated with exercise tolerance and cardiovascular fitness as indicated

Funding Sharmila Dorbala is supported by NIH RO1 Grant (RO1 HL 130563) and American Heart Association Grant (AHA 16 CSA 2888 0004).

Reprint requests: Yiu Ming Khor, MBBS, MMed, MRCP, Department of Nuclear Medicine and Molecular Imaging, Singapore General Hospital, 16 College Road, Block 2 Basement 1, Singapore 169854, Singapore; khor.yiu.ming@singhealth.com.sg

J Nucl Cardiol 2020;27:1934-8.

$1071-3581 / \$ 34.00$

Copyright (c) 2020 American Society of Nuclear Cardiology. by peak metabolic equivalents (METs) and heart rate recovery (HRR). The investigators concluded that regional quantification of skeletal muscle perfusion reserve using SPECT/CT perfusion imaging can serve as a non-invasive correlate to exercise tolerance and cardiovascular fitness at no additional radiotracer injection, stress testing, or time spent in hospital.

As the investigators described, the study had a few limitations. The sample size was relatively small $(\mathrm{n}=31)$ with predominantly male $(81 \%)$. None of the subjects had peripheral arterial disease (PAD) and only 1 subject experienced claudication during exercise, which did not result in early termination of the stress test protocol. We also do not know whether medication (e.g., antithrombotic therapy, nitrates, lipid-lower medication) or lifestyle factor (e.g., smoking) might have influenced the lower extremities perfusion reserves. Thus, as suggested by the investigators, further studies including a wider spectrum of patients, such as patients with PAD and diabetes mellitus, will advance our understanding on the pathophysiological axis between PAD and regional alterations in lower extremities perfusion reserve.

The investigators chose peak METs and HRR as surrogate markers of exercise tolerance and cardiovascular fitness. While peak METs and HRR are reasonable choices given that they are routinely measured during exercise stress testing and are predictors of long-term mortality, peak METs is effort dependent and often overestimates cardiorespiratory fitness. ${ }^{2}$ Measuring the maximal oxygen uptake (VO2max) via cardiopulmonary exercise testing (CPET) requires specialized equipment and is more costly and time consuming but is the gold standard for measuring cardiorespiratory fitness ${ }^{3}$ and 
may be the preferred assessment tool to definitively establish that skeletal muscle perfusion reserve correlates with functional capacity.

Another potentially important limitation is the inherent challenges in quantitation with SPECT or SPECT/CT imaging. Unlike PET/CT, absolute quantitation with SPECT or SPECT/CT is a field of ongoing research and is not routinely performed in clinical settings. Quantitation is validated only in certain SPECT/ CT machines, applied with specific reconstruction parameters (iterative reconstructions, scatter correction and attenuation correction etc.) and analyzed with vendor-specific software, which may not be available in many centers, especially in centers which primarily perform cardiac imaging.

Despite these limitations, this is an important pilot study demonstrating feasibility of SPECT/CT in imaging of perfusion in the lower extremities. An obvious clinical application of skeletal muscle perfusion imaging is in diagnosing PAD and assessing response to reperfusion therapy. PAD affects 202 million people worldwide ${ }^{4}$ and is associated with significant morbidity, mortality and quality of life impairment. Diagnosing PAD is challenging as symptoms are variable and current diagnostic tests have many limitations. The most widely used ankle-brachial index is technically difficult in diabetic patients with non-compressible vessels and has not been shown to accurately predict wound healing or acute limb ischemia. Anatomic imaging such as CT or magnetic resonance (MR) angiography measure blood flow in the lower extremities but are merely surrogate markers for tissue perfusion. ${ }^{5}$ Furthermore, there is no objective assessment tool to predict which patients will benefit most from revascularization. ${ }^{6}$ Non-invasive tissue perfusion imaging using SPECT/CT may be able to address these unmet clinical needs. Besides PAD, skeletal muscle perfusion imaging may be applied to study the complex interplay among skeletal muscle pump, sympathetic nervous system, and cardiovascular system which is increasingly recognized in physiological processes, such as maintenance of postural stability ${ }^{7}$, regulation of blood pressure during exercise ${ }^{8,}$ and elite athletic performance ${ }^{9}$, just to name a few.

The current study is a significant addition to the accumulating literature on imaging muscle perfusion using a variety of PET and SPECT tracers (Table 1) because it demonstrates for the first time that calf muscle perfusion reserve is significantly associated with indicators of exercise capacity and cardiovascular fitness. As an organ which receives up to $90 \%$ of blood flow during exercise $^{9}$, the skeletal muscle system and quantification of blood flow to it deserve more attention. SPECT imaging of lower extremities with myocardial perfusion agent began with thallium-201 in 1980s but poor image quality and high radiation dose had led to its declining popularity in cardiac and peripheral extremities imaging. Approved for clinical use in 1990, Tc-99m sestamibi has superior imaging and dosimetry characteristics and was evaluated in 1991 for semi-quantitative measurement of lower limb perfusion in healthy individuals and patients with suspected PAD. ${ }^{10}$ Another study in 1992 confirmed high sensitivity (91\%) and specificity (94\%) of Tc-99m sestamibi scintigraphy in diagnosing PAD associated with high correlation with angiographic and Doppler ultrasonographic findings. ${ }^{11}$ Dabrowski et al in 2003 found Tc-99m sestamibi scintigraphy superior to Doppler ultrasonography in demonstration of improved blood supply after lumbar sympathectomy. ${ }^{12}$ More recently, Manevska et al described normal values of lower limb muscle perfusion indices using Tc-99m sestamibi in 30 patients with no history of PAD and normal findings on Doppler ultrasonography and pedobranchial index of the lower extremities. One of the measured indices is perfusion reserve of the entire calf muscle group, not individual muscle like the current study by Chou et al. Age has no significant impact, consistent with the current study. ${ }^{13}$ Adoption of these cut-off values in a multi-center and multi-vendor setting will require a standardized approach with respect to image acquisition, reconstruction and analysis. The same group further refined the stress-rest lower limb perfusion scintigraphic method to a one-day protocol and showed that perfusion reserve in patients with diabetes mellitus was significantly lower than those without. $^{14}$ Another commonly used Tc-99m-labeled myocardial perfusion agent, Tc-99m tetrofosmin, had also been utilized for evaluation of skeletal muscle blood flow and assessment of response to therapy in PAD patients. ${ }^{15,16}$

In addition to SPECT imaging, peripheral extremities imaging had also been performed with PET. Advantages of PET are superior image quality, inherent ability to perform quantification, and low radiation dose. Radiotracers which had been evaluated include N-13 ammonia for measuring perfusion in the upper limbs ${ }^{17}$ and $\mathrm{O}-15$ water for calf muscle blood flow. ${ }^{18}$ However, its relatively high cost and limited availability potentially confine the clinical application of this nuclear technique of imaging skeletal muscle perfusion to specialized centers with on-site cyclotrons.

The potential of SPECT imaging of blood flow in the lower extremities is promising and expansive. Chou et al demonstrated that the study protocol can be replicated in a routine clinical setting with no requirement for specialized equipment and at no additional radiotracer injection or time spent for the patients, making it a lowhanging fruit for centers interested in providing it as a clinical service. Bolstered by continuing advancement in 
Table 1. Summary of studies on non-invasive muscle perfusion imaging using SPECT and PET tracers

\begin{tabular}{|c|c|c|c|c|c|}
\hline Radiotracer & Study & Year & $\begin{array}{l}\text { Number of } \\
\text { subjects }\end{array}$ & Scan protocol & $\begin{array}{l}\text { Semi-quantitative/ } \\
\text { quantitative metric }\end{array}$ \\
\hline \multicolumn{6}{|l|}{ SPECT tracer } \\
\hline \multirow[t]{5}{*}{$\begin{array}{l}\text { Tc-99m } \\
\text { sestamibi }\end{array}$} & $\begin{array}{l}\text { Sayman } \\
{\text { et } \mathrm{al}^{7}}^{7}\end{array}$ & 1991 & $\begin{array}{l}18 \text { with } \\
\text { claudication pain } \\
\text { vs } 6 \text { controls }\end{array}$ & $\begin{array}{l}\text { One-day protocol: rest } \\
\text { followed by stress }\end{array}$ & $\begin{array}{l}\text { Left/right calf ratio, left/ } \\
\text { right thigh ratio, }(E-I) / \\
E, \sqrt{ }\left(\mathrm{E}^{2}-\mathrm{I}^{2}\right) /(\mathrm{E}+\mathrm{I}) \\
\text { where } \mathrm{E} \text { is average } \\
\text { counts of exercise and } \\
\text { is average counts of rest } \\
\text { study }\end{array}$ \\
\hline & Miles et al ${ }^{8}$ & 1992 & $\begin{array}{l}11 \text { suspected PVD } \\
\text { vs } 9 \text { controls }\end{array}$ & Two-day protocol & $\begin{array}{l}\text { Uptake index }=\text { Muscle } \\
\text { group activity/whole } \\
\text { body activity, calf flow } \\
\text { reserve index }=\text { exercise } \\
\text { uptake index/rest } \\
\text { uptake index } \times \text { exercise } \\
\text { uptake index }\end{array}$ \\
\hline & $\begin{array}{l}\text { Dabrowski } \\
\text { et al }{ }^{9}\end{array}$ & 2003 & $\begin{array}{l}30 \text { chronic PVD } \\
\text { diagnosed by } \\
\text { ultrasonography } \\
\text { and/or } \\
\text { arteriography }\end{array}$ & $\begin{array}{l}\text { Scintigraphy was } \\
\text { performed in the week } \\
\text { before lumbar } \\
\text { sympathectomy and } \\
\text { within 6-7 days after } \\
\text { procedure }\end{array}$ & $\begin{array}{l}\text { Left/right calf ratio, left/ } \\
\text { right thigh ratio }\end{array}$ \\
\hline & $\begin{array}{l}\text { Manevska } \\
\text { et } \mathrm{al}^{10}\end{array}$ & 2017 & $\begin{array}{l}30 \text { asymptomatic } \\
\text { subjects }\end{array}$ & $\begin{array}{l}\text { One-day protocol: rest } \\
\text { followed by stress }\end{array}$ & $\begin{array}{l}\text { Left/right calf ratio, left/ } \\
\text { right thigh ratio, } \\
\text { perfusion reserve }= \\
\text { (radioactivity in calf in } \\
\text { stress }- \text { radioactivity in } \\
\text { calf in rest) } / \text { radioactivity } \\
\text { in calf in rest } \times 100 \%\end{array}$ \\
\hline & $\begin{array}{l}\text { Manveska } \\
\text { et al }^{11}\end{array}$ & 2018 & $\begin{array}{l}13 \text { diabetic vs } 11 \\
\text { non-diabetic, all } \\
\text { asymptomatic } \\
\text { for PVD }\end{array}$ & $\begin{array}{l}\text { One-day protocol: rest } \\
\text { followed by stress }\end{array}$ & $\begin{array}{l}\text { As above, time of } \\
\text { maximum activity in the } \\
\text { early arterial phase, } \\
\text { percentage } \\
\text { accumulation of the } \\
\text { radiotracer in the } 1 \text { st } \\
\text { minute }\end{array}$ \\
\hline \multirow[t]{2}{*}{$\begin{array}{l}\text { Tc-99m } \\
\text { tetrofosmin }\end{array}$} & $\begin{array}{l}\text { Miyamoto } \\
\text { et al. }{ }^{12}\end{array}$ & 2004 & $\begin{array}{l}12 \text { severe chronic } \\
\text { PVD }\end{array}$ & $\begin{array}{l}\text { Scintigraphy was } \\
\text { performed before } \\
\text { autologous bone } \\
\text { marrow cell } \\
\text { implantation and } 6 \\
\text { months after } \\
\text { implantation }\end{array}$ & Muscle-to-brain ratio \\
\hline & Chou et al ${ }^{1}$ & 2020 & $\begin{array}{l}31 \text { asymptomatic } \\
\text { subjects }\end{array}$ & $\begin{array}{l}\text { One-day protocol: stress } \\
\text { followed by rest }\end{array}$ & $\begin{array}{l}\text { Perfusion reserve }= \\
\text { (radioactivity in calf in } \\
\text { stress }- \text { radioactivity in } \\
\text { calf in rest)/radioactivity } \\
\text { in calf in rest } \times 100 \%\end{array}$ \\
\hline
\end{tabular}


Table 1 continued

\begin{tabular}{|c|c|c|c|c|c|}
\hline Radiotracer & Study & Year & $\begin{array}{l}\text { Number of } \\
\text { subjects }\end{array}$ & Scan protocol & $\begin{array}{l}\text { Semi-quantitative/ } \\
\text { quantitative metric }\end{array}$ \\
\hline \multicolumn{6}{|l|}{ PET tracer } \\
\hline $\begin{array}{l}\mathrm{N}-13 \\
\text { ammonia }\end{array}$ & $\begin{array}{l}\text { Scholtens } \\
\text { et al }\end{array}$ & 2011 & $\begin{array}{l}45 \text { with cardiac } \\
\text { pathologies vs } \\
13 \text { healthy } \\
\text { controls }\end{array}$ & $\begin{array}{l}\text { One-day protocol: rest } \\
\text { followed by stress }\end{array}$ & $\begin{array}{l}\text { Perfusion of proximal } \\
\text { upper limb was } \\
\text { calculated by two tissue } \\
\text { compartmental } \\
\text { modeling. Perfusion } \\
\text { reserve was calculated } \\
\text { by dividing perfusion of } \\
\text { stress by rest }\end{array}$ \\
\hline O-15 water & $\begin{array}{l}\text { Kalliokoski } \\
\text { et al }{ }^{15}\end{array}$ & 2008 & 8 healthy controls & $\begin{array}{l}\text { One-day protocol: rest } \\
\text { followed by stress }\end{array}$ & $\begin{array}{l}\text { Perfusion to lower limb } \\
\text { muscle groups was } \\
\text { calculated by one tissue } \\
\text { compartmental } \\
\text { modeling }\end{array}$ \\
\hline
\end{tabular}

SPECT quantitation capabilities, further research using nuclear techniques may develop an imaging biomarker for PAD and teach us more about the physiology of skeleton muscle perfusion and its relationship with the cardiovascular and nervous system.

\section{Author Contributions}

$Y M K$ and SD were responsible for manuscript preparation.

\section{Disclosure}

$Y M K$ declares that she has no conflict of interest. SD has received consulting fees from Pfizer, GE Health Care, and $A A A$; research grants from Pfizer.

\section{References}

1. Chou TH, Janse S, Sinusas AJ, Stacy MR. SPECT/CT imaging of lower extremity perfusion reserve: A non-invasive correlate to exercise tolerance and cardiovascular fitness in patients undergoing clinically-indicated myocardial perfusion imaging. J Nucl Cardiol 2020.

2. Franklin BA, Brinks J, Berra K, Lavie CJ, Gordon NF, Sperling LS. Using metabolic equivalents in clinical practice. Am J Cardiol 2018;121:382-7.

3. Fletcher GF, Ades PA, Kligfield P, Arena R, Balady GJ, Bittner VA, et al. Exercise standards for testing and training. Circulation 2013;128:873-934.

4. Fowkes FGR, Rudan D, Rudan I, Aboyans V, Denenberg JO, McDermott MM, et al. Comparison of global estimates of prevalence and risk factors for peripheral artery disease in 2000 and 2010: A systematic review and analysis. Lancet 2013;382:1329-40.

5. Misra S, Shishehbor MH, Takahashi EA, Aronow HD, Brewster LP, Bunte MC, et al. Perfusion assessment in critical limb ischemia: Principles for understanding and the development of evidence and evaluation of devices: A scientific statement from the American Heart Association. Circulation 2019;140:e657-72.

6. Gerhard-Herman MD, Gornik HL, Barrett C, Barshes NR, Corriere MA, Drachman DE, et al. AHA/ACC guideline on the management of patients with lower extremity peripheral artery disease Executive summary: A report of the American College of Cardiology/American Heart Association Task Force on Clinical Practice Guidelines. Circulation 2017;135:686-725.

7. Verma AK, Garg A, Xu D, Bruner M, Fazel-Rezai R, Blaber AP, et al. Skeletal muscle pump drives control of cardiovascular and postural systems. Sci Rep 2017;7:45301.

8. Calbet JAL, Lundby C. Skeletal muscle vasodilatation during maximal exercise in health and disease. J Physiol 2012;590:628596.

9. Joyner MJ, Casey DP. Regulation of increased blood flow (hyperemia) to muscles during exercise: A hierarchy of competing physiological needs. Physiol Rev 2015;95:549-601.

10. Sayman HB, Urgancioglu I. Muscle perfusion with technetiumMIBI in lower extremity peripheral arterial diseases. J Nucl Med 1991;32:1700-3.

11. Miles KA, Barber RW, Wraight EP, Cooper M, Appleton DS. Leg muscle scintigraphy with 99Tcm-MIBI in the assessment of peripheral vascular (arterial) disease. Nucl Med Commun 1992;13:593-603.

12. Dabrowski J, Mikosiński J, Kuśmierek J. Scintigraphic and ultrasonographic assessment of the effect of lumbar sympathectomy upon chronic arteriosclerotic ischaemia of lower extremities. Nucl Med Rev Cent East Eur 2003;6:17-22.

13. Manevska N, Stojanoski S, Pop Gjorceva D, Todorovska L, Miladinova D, Zafirova B. Normal values of tissue-muscle 
perfusion indexes of lower limbs obtained with a scintigraphic method. PRILOZI 2017;38:55-61.

14. Manevska N, Stojanoski S, Pop Gjorceva D, Todorovska L, Vavlukis M, Majstorov V. Tissue-muscle perfusion assessed by one day $(99 \mathrm{~m}) \mathrm{Tc}-\mathrm{MIBI}$ rest-dipyridamol scintigraphy in non-diabetic and diabetic patients. Rev Esp Med Nucl Imagen Mol 2018;37:141-5.

15. Miyamoto M, Yasutake M, Takano H, Takagi H, Takagi G, Mizuno $\mathrm{H}$, et al. Therapeutic angiogenesis by autologous bone marrow cell implantation for refractory chronic peripheral arterial disease using assessment of neovascularization by $99 \mathrm{mTc}$-tetrofosmin (TF) perfusion scintigraphy. Cell Transpl 2004;13:429-37.

16. Stacy MR, Zhou W, Sinusas AJ. Radiotracer imaging of peripheral vascular disease. J Nucl Med Technol 2015;43:185-92.
17. Scholtens AM, Tio RA, Willemsen A, Dierckx RA, Boersma HH, Zeebregts CJ, et al. Myocardial perfusion reserve compared with peripheral perfusion reserve: A [13N]ammonia PET study. J Nucl Cardiol 2011;18:238-46.

18. Kalliokoski KK, Kemppainen J, Larmola K, Takala TO, Peltoniemi $\mathrm{P}$, Oksanen $\mathrm{A}$, et al. Muscle blood flow and flow heterogeneity during exercise studied with positron emission tomography in humans. Eur J Appl Physiol 2000;83:395-401.

Publisher's Note Springer Nature remains neutral with regard to jurisdictional claims in published maps and institutional affiliations. 